\title{
Is Economic Cooperation Framework Agreement the Threshold of Sustainable Development for Taiwan's Industries?
}

\author{
Tzu-Chun Sheng ${ }^{1} \&$ Shu-Hui Lan ${ }^{2}$ \\ ${ }^{1}$ Department of Finance, Ling Tung University, Taiwan, ROC \\ ${ }^{2}$ Department of Marketing and Logistics Management, Ling Tung University, Taiwan, ROC \\ Correspondence: Shu-Hui Lan, Department of Marketing and Logistics Management, Ling Tung University, \\ Taichung City, Taiwan, R.O.C. Tel: 886-981-028-048. E-mail: cammylan@teamail.ltu.edu.tw
}

Received: March 25, 2014

Accepted: March 31, 2014

Online Published: May 25, 2014

doi:10.5539/ijef.v6n6p38

URL: http://dx.doi.org/10.5539/ijef.v6n6p38

\begin{abstract}
Taiwan and the PRC signed the Economic Cooperation Framework Agreement (ECFA) on 29th June, 2010. From 2008 to 2013, while the two parties were signing ECFA, Straits Exchange Foundation (SEF) and Association for Relations across the Taiwan Straits (ARATS) discontinuously held nine meetings in total and signed nineteen agreements and one mutual declaration. The key points which influence the sustainable development of Taiwan's industries are the early harvest list and the agreement on servicing trade markets on both sides, and the related standard of cooperation with financial institutions. Except from the clauses in ECFA, the most important appendixes are Enclosure No.1, "Early Harvest List of Products Trade and Tariff Reduction Arrangement", Enclosure No.3, "Dual-side Defensive Measures on Early Harvest Products", and Enclosure No.4, "Servicing Trade on Early Harvest and Open Measures". The appendixes explain specific agreements and norms on the opening of cross-strait trading. This article is an analysis of the clauses and appendixes of ECFA, for understanding if ECFA is a beginning step of sustainable development for Taiwan's industries.
\end{abstract}

Keywords: economic cooperation framework agreement, free trade zone, regional economic integration

\section{Introduction}

A large number of Chinese elites gathered together in Taiwan in 1949 due to the civil war. For a country, it is important to set the foundation stone for the economic miracle to occur in the future. The Taiwan government implemented agrarian reform in addition to a number of various economic development programs. Mainland China didn't implement any open reforms until the Cultural Revolution. In the initial period of economic reformation, the Taiwan government adopted a policy which limited Taiwanese manufacturers from investing in China. At that time, Taiwanese funds almost all entered into China going through a third point of entry, such as Hong Kong or some other region in Southeast Asia. Afterwards, the Taiwan government removed financial controls that relieved the relationship between Taiwan and China. In China, Chinese central bank and local governments implemented several preferential measures and incentives. These encouraged Taiwan's businessmen to speed up their investment for helping China's rapid economic development. According to Scalapino (1995), when the political controversies and barriers which obstructed cooperation between Taiwan and China disappeared, spontaneous economic and complementary development took place, and there were more opportunities to develop economic cooperation. Under the government's attitude of "neither support nor oppose", Natural Economic Territory may have opportunities to grow and follow the system of a free market and operate naturally.

Scalapino (1995) exactly matched Taiwan and China's model of economic and trade during these twenty years. In February of 1991 Taiwan passed the "Guidelines for National Unification", to be the primary basis for strategies in regards to China, and for cross-strait relationships. In 1992, Taiwan started to promote the short-term plans for Guidelines for National Unification. Taiwan and Chinese governments seemed to remain fixed at an unbridgeable gap on the standpoints of politics and national authority. Both sides seemed to have an unspoken consensus in the issues of developing the economies and investing as well. Industries of Taiwan need subsistence based on China's low-priced labor and low production cost for its own manufacturers. On the other hand, China needs investments from Taiwanese manufacturers in order to absorb the funds, manpower, and experience, so they can grow stably and progressively. 
In practice, however, signing ECFA is not an achievement in economic cooperation. The goal of signing ECFA is not a matter to simply be rushed into. In the future, the list of economic and trade goals which both sides have agreed to cooperate on and develop need further negotiations. Therefore, the major meaning of ECFA is to reach a common consensus on the problems which have already been in existence on both sides and remain unsolved. It is important to build a cooperation system beneficial to developing collaboration and both sides' economic prosperity.

This article is an analysis of the influences of signing ECFA toward Taiwan industries, based on clauses and annexes in ECFA. First of all, import and export trade and investment situation between Taiwan and China from 2000 to 2013 were presented. Then, the background, the specific contents and related literature review of CEPA, ECFA, and cross-strait regional economic integration were described, as well as the Taiwan government's main purposes of promoting ECFA. This article further analyzed the controversial issues caused by ECFA by illustrating the specific contents of ECFA and cross-strait negotiation process. Finally, the conclusion was proposed.

\section{The Space-Time Background of Cross-Strait Signing ECFA}

As Table 1 shows, in recent years, although the investments in China from Taiwanese manufacturers have declined, both the investment items and amount invested still occupy a large percentage of the total amount of investment. Another thing to be looked at, as Table 2 shows, is that trade between Taiwan and China over the previous year's statistics show that the total amount of bilateral trade and trade surplus has increased. In other words, Taiwanese manufacturers have become more and more dependent on the expanding large market in China. Recently, China's import trade amount from Taiwan has been gradually increasing.

Table 1. Statistics of the investment of Taiwanese manufacturers from 2000 to 2013

\begin{tabular}{ccccc}
\hline \multirow{2}{*}{ Year } & \multicolumn{2}{c}{ Number of items } & \multicolumn{2}{c}{ Used amount of Taiwanese funds } \\
\cline { 2 - 5 } & Quantity & Growth (\%) & Amount(Billion USD) & Growth (\%) \\
\hline 2000 & 3108 & 24.4 & 2.30 & -11.7 \\
2001 & 4214 & 35.6 & 2.98 & 29.8 \\
2002 & 4853 & 15.2 & 3.97 & 33.3 \\
2003 & 4495 & -7.4 & 3.38 & -14.9 \\
2004 & 4002 & -11.0 & 3.12 & -7.7 \\
2005 & 3907 & -2.4 & 2.16 & -31.0 \\
2006 & 3752 & -4.0 & 2.14 & -0.7 \\
2007 & 3299 & -12.1 & 1.77 & -20.4 \\
2008 & 2360 & -28.5 & 1.90 & 7.0 \\
2009 & 2555 & 8.3 & 1.88 & -1.0 \\
2010 & 3072 & 20.2 & 2.48 & 31.7 \\
2011 & 2639 & -14.1 & 2.18 & -11.8 \\
2012 & 2229 & -15.5 & 2.85 & 30.4 \\
2013 & 2017 & -9.5 & 2.09 & -26.7 \\
\hline
\end{tabular}

Note. Source: Ministry of Commerce of the People's Republic of China, Department of Taiwan, Hong Kong and Macao Affairs (http://tga.mofcom.gov.cn).

Table 2. Statistics of the trade between Taiwan and China from 2000 to 2013

\begin{tabular}{|c|c|c|c|c|c|c|c|}
\hline \multirow[b]{2}{*}{ Year } & \multicolumn{2}{|c|}{ Total trade } & \multicolumn{2}{|c|}{ China export amount with Taiwan } & \multicolumn{2}{|c|}{ China import amount with Taiwan } & \multirow[b]{2}{*}{$\begin{array}{l}\text { Trade } \\
\text { surplus }\end{array}$} \\
\hline & Amount & $\begin{array}{l}\text { Year-on-year } \\
\text { growth }(\%)\end{array}$ & Amount & $\begin{array}{l}\text { Year-on-year } \\
\text { growth (\%) }\end{array}$ & Amount & $\begin{array}{l}\text { Year-on-year } \\
\text { growth (\%) }\end{array}$ & \\
\hline 2000 & 30.53 & 30.1 & 5.04 & 27.6 & 25.49 & 30.6 & -20.45 \\
\hline 2001 & 32.34 & 5.9 & 5.00 & -0.8 & 27.34 & 7.2 & -22.34 \\
\hline 2002 & 44.67 & 38.1 & 6.59 & 31.7 & 38.08 & 39.3 & -31.49 \\
\hline 2003 & 58.36 & 30.7 & 9.00 & 36.7 & 49.36 & 29.7 & -40.36 \\
\hline 2004 & 78.32 & 34.2 & 13.55 & 60.4 & 64.78 & 31.2 & -51.23 \\
\hline 2005 & 91.23 & 16.5 & 16.55 & 22.2 & 74.68 & 15.3 & -58.13 \\
\hline 2006 & 107.84 & 8.2 & 20.74 & 25.3 & 87.11 & 16.6 & -66.37 \\
\hline 2007 & 124.48 & 15.4 & 23.46 & 13.1 & 101.02 & 16.0 & -77.56 \\
\hline
\end{tabular}




\begin{tabular}{|c|c|c|c|c|c|c|c|}
\hline 2008 & 129.22 & 3.8 & 25.88 & 10.3 & 103.34 & 2.3 & -77.46 \\
\hline 2010 & 145.37 & 36.9 & 29.68 & 44.8 & 115.69 & 35.0 & -86.01 \\
\hline 2012 & 168.96 & 5.6 & 36.78 & 4.8 & 132.18 & 5.8 & -95.40 \\
\hline 2013 & 197.28 & 16.7 & 40.64 & 10.5 & 156.64 & 18.5 & -116.00 \\
\hline
\end{tabular}

Note. Source: Ministry of Commerce of the People's Republic of China, Department of Taiwan, Hong Kong and Macao Affairs (http://tga.mofcom.gov.cn).

After experiencing the shock and impact of a financial tsunami, emerging market countries are gradually replacing developed countries, becoming a major source of global economic growth. Especially in the G20 summit, China is bound to play a more important role in the international politics and economic arena. In recent years, the effectiveness of China's economy has a striking development. Today, without the US, China has already surpassed Japan and became the second largest economy in the world. Its position of world economy cannot be ignored. Also, China is the largest holder of foreign exchange and the market for various commodities. Moreover, China has gradually replaced the U.S.A. as Taiwan's most important trading partner. In 2010, the trade amount between both sides reached to $\$ 145.4$ billion, thereby accounting for $27 \%$ of the foreign trade amount of Taiwan. On the other hand, China is also the largest export market for Taiwan. In 2010, nearly $41.8 \%$ of Taiwan's exports, a value totaling \$115.7 billion were exported to China. In the same year, China was also the second largest source of imports in Taiwan. Furthermore, China is also the largest foreign investor in Taiwan, with an accumulation totaling $\$ 97$ billion, accounting for $56.44 \%$ of Taiwan's foreign investment total. Some studies have pointed out that Taiwan's industry is not only growing demand in China, but also indirectly accelerating in the economics of marginalization (Taiwan Ratings Corporation, TRC, 2009).

The economic model in Taiwan is long-term international trade-oriented, and it is not independent of global economic unsettlement and the impact of societal issues. In 2008 and 2011, western countries encountered a series of financial crises one after another. Many economic and financial experts brought up warnings about worldwide unemployment, uneven distribution of wealth, national debt, aging populations, and economic development. None of the countries have yet come up with solutions to solve these different kinds of economic and social crises. Taiwan has to face not only the above issues, but also the impact of regional economic integration. The current Asian countries aligned and formed the group of "ASEAN 10 plus 1" and "ASEAN 10 plus 3" (ten countries of ASEAN plus China, Japan and Korea). Every country will possess the preference of customs reduction in the free trade area. As soon as the international trade situation is formed, it will have a negative influence on the structure of Taiwan's industries. Society will not be able to endure it. In order to evade customs and obtain much cheaper producible resources, more manufacturers may move their factories to China or South-East Asian Countries. This phenomenon of industrial relocation will lead the decline of the domestic investment environment.

In order to establish a closer economic and trading relationship with China, and further prevent Taiwan industries from being marginalized in the highly competitive international commercial environment, Taiwan's president Ying-Jeou Ma officially announced and promoted the signing of ECFA on February $27^{\text {th }}, 2009$. This means Taiwan and China will start discussions on the issues of investment, economic cooperation, commodity and service trade, and early profits.

Ministry of Economic Affairs proposed the "ECFA Economic Impact Assessment Report", explaining the advantages and disadvantages of economic development. The result shows Taiwan's economic growth will rise $1.65 \%$ to $1.72 \%$ after signing ECFA, and within 7 years the Foreign Direct Investment (FDI) will reach the amount of US\$0.89 billion. On April 25, 2010, President Ying-Jeou Ma and chairwoman of the Democratic Progressive Party (DPP) Ying-Wen Tsai started a live TV debate on ECFA. Both parties debated on the issue about the changing of economics in Taiwan, the unemployment rate, official allowance in business measures, business upgrading and margining, the international standing of Taiwan's industries, and global strategies after signing ECFA. On June 29, 2010, both representatives officially signed ECFA in Chongqing, China, and it has been valid since September 12, 2010. On January 1, 2011, the merchandise taxes under the Early Harvest List began being lowered. Taiwan and China had officially entered the new era of ECFA. At the same time, the Straits Exchange Foundation and the Association for Relations across the Taiwan Straits, held meetings seven times at the Jiang-Chen Summit, and signed many cooperation agreements. The Taiwan government then started trying to push Taiwan's industries toward an international standard level through cooperation with China. 


\section{CEPA, ECFA, and Cross-Strait Regional Economic Integration}

Through a comprehensive survey about the concept of free trade area and the regional economic integration, scholars generally think that regional economic integration is very important all over the world. (Mario \& Ernst, 1969; Karl, 1978; Scalapino, 1995; Shaun, 2000). All countries pursued the goal of trade liberalization and tried to find ways out of the problems of industrial upgrading. On one hand, they joined global economics and trade organizations and engaged in tariff negotiations, such as the WTO. On the other hand, they joined regional economic organizations and trade organizations such as FTA, EU, ASEAN and AFTA. Take ASEAN for example, the total GDP of ASEAN was US\$672.14 billion in 2000. In 2010, the total GDP grew over US\$1.8 trillion. This proved that the concept of regional economic integration is important to a single country or an alliance.

In addition to the rapid integration of the East Asia area, there are 276 countries signing with free trade agreements (FTA) or regional trade agreements (RTA) all over the world. In the foreseeable future, the global economic situation will be influenced by globalism and economic regionalism. To consider the pros and cons of the whole economic development, all the countries around the world must achieve balance between them. Due to the economics and trade issue and the profit, the situation of competition and cooperation between countries is becoming more and more obvious. After going through the financial crisis in 2008, countries paid more attention to international trade protectionism and the pattern of regional economics trading.

After China's government withdrew the sovereignty of Hong Kong in 1997, Hong Kong encountered its own Asian financial crisis and one economic downturn after another. To make the economical cooperation more frequent and stop democratic political revolutions, China signed two treaties, Closer Economic Partnership Arrangement (CEPA) with Hong Kong and Macao separately in 2003 and 2008. In the box of "One China", CEPA is regarded as an impossible case in a normal situation where signing free trade agreement two sides.

The main content of CEPA includes measures to gradually achieve three liberalizations in China, Hong Kong, and Macao. These three liberalizations include trade liberalization, service liberalization, and investment liberalizations. The main development process could be divided into six parts. The first step is to gradually make traveling to Hong Kong and Macao open to Chinese in each city. Opening China to professional certification for access for Hong Kong and Macau residents is the second step. Then, they will put some personnel in service industry in exchange. The use of the Renminbi and insurance business to Hong Kong and Macau will then be implemented step-by-step. The fifth is to bring zero charge for custom duties into practice. The final step is to introduce professions such as law, finance, and architecture into the Chinese market.

For manufacturers in Hong Kong and Macao, the practice of CEPA has a more symbolic meaning than actual meaning. Manufacturers had already moved to China. In addition, Hong Kong and Macao had already been key free harbors in Asia. Therefore there were no existing tariff problems. CEPA provided more help towards Hong Kong and Macao's bank, financial, tourism, and service industry. On the contrary, China opened the gate for cooperation to Hong Kong and Macao based on CEPA, using the chance to show the sincerity and confidence of their trading and economic cooperation. Therefore, the content and contract background of CEPA is $n$ exceptional.

Taiwan and China's trade and economic cooperation relationship changed after joining the WTO to be the 144th and 143th member countries one after another at the end of 2001 and the beginning of 2002. Under WTO's standards, Taiwan and China both participate in international economic and trading activities. Taiwan was then temporarily able to obtain indemnification of economic and trading profits, as well as fix its marginalized international standing, while China officially entered the list of major trading countries. However, under the constitution of WTO, the problems that have existed for a long time between Taiwan and China still can't be solved. For example, problems such as customs, trade barriers, the liberty of the financial service industry, the limits for investment, the agreements for economic cooperation, the limits of imports and exports for a large array of merchandise and agricultural products, and so on. There are still many economic issues, discontinuous conversations, and trade conflicts for the two parties that require negotiations.

After Mr. Ma was elected as President of Taiwan in 2008, he strove hard to solve the long-existing problems mentioned above while not violating Taiwan's constitution but conforming to the 3 National Policies at the same time - demand of the country, supports of the citizens, and supervision from the Congress. This is how the idea of signing ECFA was cultivated. The Taiwan government hopes to lead local industries to enter the immense China market by signing ECFA with China, and indirectly take the advantage to take the challenge of the international markets. Different from CEPA agreement China signed with Hong Kong and Macau as Taiwan and China are two opposite members in WTO ECFA was signed by the two parties have to be announced to the committee of TWO in advance and they need to obey WTO's relevant regulations. As shown in table 3, during 
the time when the two parties were signing ECFA, SEF and ARATS held nine meetings in total and signed nineteen agreements and one mutual declaration.

Table 3. SEF (Straits Exchange Foundation) and ARATS' (Association for Relations across the Taiwan Straits) 19 agreements in high-level cross-strait talks as well as the joint declaration

\begin{tabular}{|c|c|c|}
\hline Cross-Strait negotiation & Time & Agreements and Joint Declaration \\
\hline \multirow[t]{2}{*}{ The 1st Chiang-Chen Summit } & Jun. 13,2008 & The Summary of Cross-Strait Charters \\
\hline & & $\begin{array}{l}\text { The Agreement that was signed for mainland tourists' travel to Taiwan } \\
\text { island }\end{array}$ \\
\hline \multirow[t]{4}{*}{ The 2nd Chiang-Chen Summit } & Nov. 4, 2008 & The Agreement of Cross-Strait Airlift \\
\hline & & The Agreement of Cross-Strait Ocean Shipping \\
\hline & & The Agreement of Cross-Strait Politics \\
\hline & & The Agreement of Cross-Strait Food Safety \\
\hline \multirow[t]{2}{*}{ The 3rd Chiang-Chen Summit } & Apr. 26, 2009 & $\begin{array}{l}\text { The Cooperation Agreement of Striking Crime and Mutual Judicial } \\
\text { Assistance }\end{array}$ \\
\hline & & $\begin{array}{l}\text { The Cooperation Agreement of Finance } \\
\text { The Additional Agreement of Cross-Strait Ocean Shipping } \\
\text { Investment Agreement of China Capital to Taiwan }\end{array}$ \\
\hline \multirow[t]{3}{*}{ The 4th Chiang-Chen Summit } & Dec. 22,2009 & $\begin{array}{l}\text { The Cooperation Agreement of Agriculture Products' Quarantine } \\
\text { Inspection }\end{array}$ \\
\hline & & $\begin{array}{l}\text { The Cooperation Agreement of Standardization Testing and } \\
\text { Certification }\end{array}$ \\
\hline & & The Cooperation Agreement of Labor Service of Shipment \\
\hline \multirow[t]{2}{*}{ The 5th Chiang-Chen Summit } & Jun. 29, 2010 & Economic Cooperation Framework Agreement(ECFA) \\
\hline & & $\begin{array}{l}\text { The Cooperation Agreement of IPR (Intellectual Property Rights) } \\
\text { Protection }\end{array}$ \\
\hline The 6th Chiang-Chen Summit & Dec. 21,2010 & The Cooperation Agreement of Cross-Strait Medical Sanitation \\
\hline The 7th Chiang-Chen Summit & Oct. 20,2011 & The Cooperation Agreement of Cross-Strait Nuclear Power Safety \\
\hline \multirow[t]{2}{*}{ The 8th Chiang-Chen Summit } & Aug. 9, 2012 & $\begin{array}{l}\text { The Cooperation Agreement of Cross-Strait Investment Protection and } \\
\text { Promotion }\end{array}$ \\
\hline & & The Cooperation Agreement of Cross-Strait Customs Cooperation \\
\hline The 9th High-Level Cross-Strait Talks & Jun. 21, 2013 & The Cooperation Agreement of Cross-Strait Trade in Services \\
\hline
\end{tabular}

Note. Source: Constructed by the authors in accordance with reviewing.

Bing-Kun Jiang, the chairman of Straits Exchange Foundation noted that many across-the-straits agreements have been signed achieved and they have held to a common consensus in the period of time from 2008 to 2011 in seventh ECFA consultative conference. The Chiang-Chen summit effectively solved the problem of interaction between China and Taiwan, establishing a foundation of mutual trust and interaction. The negotiation and interaction of the systems of Taiwan and China is a necessary basis for good developments in a cross-strait relationship, and a guarantee of peace and prosperity for the area. Both sides should continue using this foundation to maintain a long-term peace and a stable relationship, and to build an environment that benefits both sides and each other's development. In terms of property cooperation, both sides have the same vision, target, and short-term collaboration. In addition they hope to raise the level, deepen the benefit, and initiate a new aspect of this property cooperation.

Professor of Academia Sinica, C. Y. Cyrus Chu, has proposed "Chu's Spaghetti-bowl Effect Theory" to explain the concept of the relationship of the global trade. The Taiwan government expects to bring the effect of regional economic integration to Taiwan's economic and industry by signing ECFA. After signing ECFA, Taiwan will additionally sign the Free Trade Area contract with other main trading partner countries such as the US, Japan, Singapore, ASEAN countries and the EU, to build a superior, more beneficial global trading competition. Soong (2009) indicated that the most urgent cross-strait matter is to conduct economic integration and trading cooperation. Moreover, it is for the best that both sides pursue the economic cooperation together and sign the economic and trading cooperation contract. It will be a based on political mutual trust on both sides to build a negotiation mechanism and sign the peace agreement to build a peaceful environment for economic development across-the-straits for the future. C. Wu (2009) pointed out that the formation of cross-strait economic 
interdependence is a complementary division of economic elements and intense communication in economics and trade, therefore the structure should evolve and progress continuously. Yang (2009) pointed out that trade liberalization and internationalization and market opening is a worldwide trend among developed countries, including Taiwan, and is unstoppable trend. ECFA is only a beginning; in the future Taiwan should strive for more international free trade agreement (FTA) opportunities. Hsieh and Wu (2010) think that from a practical point of view and objective conditions, the signing of ECFA between Taiwan and mainland China is due to a considerable extent when the ten ASEAN countries entered into a free-trade area agreement with China in 2010 became. Therefore, the content of ECFA - the two sides' tariff reduction is an opportunity to increase trade competitiveness to the ten countries in ASEAN. Liu (2011) pointed out that the content of ECFA, the two sides' tariff reduction, an increase of Taiwan's ten countries of ASEAN's trade competitiveness. Liu (2011) pointed out that the spirit and provisions of the ECFA and WTO is a combination. It allows a better legal system of cross-strait economic and trade relations. Furthermore, it will integrate the global economic system, which is a positive benefit for Taiwan's international trade and international competitiveness.

\section{Taiwan Government's Main Purposes of Promoting ECFA}

The formal provisions of ECFA have briefly shown the main purpose and meaning for promoting the signing of ECFA. In the preface, it mentioned that the two parties agree with the basic principles of WTO and consider the economic conditions of both sides. Then they should gradually decrease or eliminate the barriers to trade and investment for each other and create a fair trade and investment environment. Through signing ECFA, they can further increase the mutual trade and investment relations, and build a cooperation mechanism which is beneficial to cross-strait economic prosperity and development. There are three goals of signing the ECFA cross-strait economic prosperities and developments. There are three goals of signing the ECFA stated in the first chapter and first rule of ECFA. First, reinforce and enhance bilateral cooperation in economics, trade, and investment. Second, further promote two-sided trade liberalization of goods and services, and establish a fair, visible and convenient investment and a protection system. The last one is to expand economic cooperation and set up cooperation mechanisms.

From the viewpoint of futurology, the signing of ECFA has great overall significance to developments in Taiwan in the future. In 2010, Hsieh and Wu pointed out that whether or not to sign the ECFA is a principle of inertial dilemma of futurology. Taiwan will have several future areas of development if they sign the ECFA. Whether to sign the ECFA or not, Taiwan will have many multiple future possibilities toward the future. The signing of ECFA certainly has objective conditions. From the viewpoint of globalization, the economic strength of one country or an area and the "potential strength" for development determine the access of a country or a region.

Generally speaking, the main purposes of ECFA consists of promoting economic cooperation, constructing cross-strait economic and trade interactive media, having an agreement for the decrease of the investments and limits of trade, and setting up a suitable controversy-solving procedure. According to WTO standards, Taiwan and China signing the ECFA is a plan which is based on their specific economic relationship with each other, hoping that both sides can begin cooperating on the status of their economy in order to improve the continuous negotiation and cooperation. Soong (2009) indicated that the meaning of meaning of ECFA is that Taiwan is able to enhance Taiwan's globalization progress through the advantage of international economic labor-division and integration from Mainland China. This method is more sensible and pragmatic than adopting a negative, resisting strategy. Yang (2009) pointed out that signing the ECFA makes the exporting industries have better competitive ability, and expecting that they would have a common consensus as soon as possible; while the domestic industries, which have less competitive ability, are afraid of becoming uncompetitive. We should know how to seek more beneficial terms through advantages and disadvantages to make every group back each other up and look forward to the of ECFA. It is not only a responsibility of government but the industrial circles should take the timing as a good opportunity to transform into another society.

In the terms of a statement from the Bureau of Foreign Trade (2011), the Taiwan government proposed the ECFA is mainly to advance the economic relationship of Taiwan and China and making it "normal". At present, China is the major exporting area to Taiwan, signing an accord with them is conducive to Taiwan to have bilateral Free Trade Agreement with other countries; moreover, Taiwan can avoid being marginalized in the fierce global commercial competition. Furthermore, signing the ECFA can promote the economic investment of Taiwan to be "international'; signing an agreement or convention with Mainland China and other countries can assist Taiwan in the International Economic System, and it would appeal to multinational enterprises to make use of Taiwan as a stepping stone to enter the economic investment media of East Asia.

According to the statement announced on the official website of ECFA, "Economic Cooperation Framework 
Agreement" (2011), the GDP of Taiwan, including the volume of trade in imports and exports, trade terms and social welfare have grown positively after cosigning ECFA and it has obviously had positive effects for the macro economy. In addition, following are some major benefits for Taiwan after cosigning ECFA, indicated by the official website of ECFA. First, ECFA will help Taiwan have the significant competitive advantage to the market in China. Secondly, Taiwan will become the first cooperative partner considered and a gateway compared to other countries. Thirdly, cosigning ECFA benefits the industrial supply chain as it can be kept in Taiwan. Fourthly, purchasing in Taiwan by Taiwanese businessmen and competing industries will increase. Fifthly, it will speed up Taiwan becoming an industrial operation center.

\section{The Main Content of the Clauses and Appendices in ECFA}

In addition to the preface, the formal provisions of ECFA were divided into five chapters and sixteen clauses. At the same time there were also five appendices referred to Table 4 and Table 5. According to the text of ECFA signed by both sides, chapter 1 explained the general principles concerning specific targets and cooperative measures, and was also regarded as a significant symbol of trade agreement between the governments of mainland China and Taiwan. From chapter 2 and chapter 3, the facts specified the relationship for both sides toward the trade and investment, and included the precise statements about the cooperative projects. Chapter 4 specified the detailed projects, clauses, and relative regulation for the initial profit of goods and services. The last chapter clarified the other regulations related to ECFA and the follow-up development.

Table 4. Chapters and clauses in ECFA

\begin{tabular}{ll}
\hline \multicolumn{1}{c}{ Chapter } & \multicolumn{1}{c}{ Clause } \\
\hline Preamble & \\
Chapter 1 General Principles & Article 1. Objectives \\
& Article 2. Cooperation Measures \\
Chapter 2 Trade and Investment & Article 3. Trade in food \\
& Article 4. Trade in business \\
& Article 5. Investment \\
Chapter 3 Economic Cooperation & Article 6. Economic cooperation \\
Chapter 4 Early Harvest & Article 7. Early harvest trade in food \\
& Article 8. Early harvest trade in service \\
Chapter 5 Other & Article 9. Exceptions \\
& Article 10. Dispute settlement \\
& Article 11. Institution arrangement \\
& Article 12. Document Formats \\
& Article 13. Annexes and Subsequent Agreements \\
& Article 14. Amendments \\
& Article 15. Entry into force \\
& Article 16. Termination \\
\hline
\end{tabular}

Note. Source: Constructed by the authors in accordance with reviewing.

Table 5. Annexes of ECFA

\begin{tabular}{ll}
\hline \multicolumn{1}{c}{ Annex } & \multicolumn{1}{c}{ Content } \\
\hline Annex I & Product list and tariff reduction arrangements under the early harvest for trade in goods \\
Annex II & Provisional rules of origin applicable to products under the early harvest for trade in goods \\
Annex III & Safeguard Measures between the two parties applicable to products under the early harvest for trade in goods \\
Annex IV & Sectors and liberalization measures under the early harvest for trade in services \\
Annex V & Definitions of service suppliers applicable to sectors and liberalization measures under the early harvest for trade in services \\
\hline
\end{tabular}

Note. Source: Constructed by the authors in accordance with reviewing.

With regards to products for trade on the early harvest list, Taiwan's tariff reduction items for China include petrochemicals, textiles, various machines, transportation equipment and other products, all totaling 267 items. China's Tariff Reduction items for Taiwan include agricultural, petrochemical, textile, various machines, transportation equipment and other products, all totaling 539 items. 
In regards to non-financial opened service trades, China promised Taiwan to open up specialized service industries on eight items: the services of accounting; auditing; bookkeeping; computer and related services of software implementation and data processing services; research and development services of the natural sciences; and engineering research and experimental development services; conference services; professional design services; audiovisual services; hospital services; and air transport services of aircraft repair and maintenance services. Taiwan promises to open up the industries in eight areas: Research and development service; conference services; exhibition services; specialty design services; film services of audio-visual services; brokerage services; sports and other entertainment services; and air services of the computer reservation systems. Of financial services, China promised Taiwan to open up the projects for the insurance and related services; banking service and other financial services but not including negotiable securities; and futures and related items. Taiwan promised to open up the banking service and other financial services, but not include negotiable securities, futures, and insurance items.

Chapter 5, Clause 11 is worth mentioning. This section refers to institutional arrangements and according to ECFA both sides must set up an "economic cooperation committee" to deal with the matters relative to the agreement, including necessary consultations to fulfill ECFA targets; including necessary consultations to fulfill ECFA targets of; supervising and assessing the execution of the agreement; explaining the regulations for the agreement; informing important economic and trade information' solving any contention about the explanations, and the execution and the application of the agreement. The ECFA economic cooperation committee is like the organizations set up after signing FTA. And the" Joint Steering Committee" set up by CEPA is based on the subordinate relationship between the central government in China and the local government in Hong Kong.

\section{The Controversial Issue Caused by ECFA-The Supporting and Opposing Points}

In fact, Taiwan isn't able to come to a consensus agreement about Ying-Jeou Ma's government signing the ECFA policy. Not only do the politicians of each political party have different opinions, the ECFA policy itself has also caused quite a controversy in academic and business circles. The standpoints of supporting or opposing depend on the basis of different advice and theories. C. Wu (2009) pointed out that in the economic and trade interaction, how to make both sides of the trade and economic interaction maintain a positive expectation, has become a critical and important issue. To balance the development of any future economic relationship, in addition to facing the reality of cross-strait economic interdependence, we also have to make both sides maintain optimistic expectations of continuous gains from the economic interaction.

Views against ECFA are mainly based on the "China Menace Theory". China Credit Company reported in "Taiwan's top 110 corporative credit and outlook" that Taiwan's top 100 enterprises depend on the Chinese Market more than before. Once the ECFA contract is signed, enterprises in Taiwan would be even more highly dependent on China. That is, ECFA may have effects on Taiwanese industries in an area of the world controlled by the Chinese Economy, national policy and the changing social environment.

C. Wu (2009) thinks that the extremely different politics and economies of the two countries would not only make Taiwan industries weaker by an irregular economy, but it also makes Taiwan controlled by China, which comes out as a loss to Taiwan. In fact, the trade dependence is a competition of the two nations. In other words, it is not a mutual dependence of the two but a tendency of Taiwan toward China, which makes Taiwan suppressed by China; thus, the investment of China needs to be limited, to avoid an over dependence upon China.

April 25, 2010, Ying-Jeou Ma, the chairperson of the Kuomintang (KMT) and the President, started a live debate on to the ECFA issue with Ying-Wen Tsai, the chairperson of the Democratic Progressive Party (DPP). This debate which was hosted by two chairpeople from both parties drew much attention. On this issue, President Ma considered the policy on China proposed by the DPP to be completely isolationist, and he also pointed out that ECFA would make Taiwan society more international and open. President Ma declared that his determination to protect Taiwan has never changed and never will no matter what was said in the debate or in any upcoming negotiations. However, Ms. Tsai criticized the KMT's policy was to "Head for the world via China" while the DPP's policy was to "Head for China with the world." Ms. Tsai claimed we shouldn't make this influential overall-economical contract with China and she also stated that this should be under the regulations of the WTO. We can see whether ECFA benefits Taiwan after the citizens fully realize what it is about, and the KMT shouldn't do what they want.

In addition, the Early Harvest List items in ECFA may continue to face regulation in the next decade. Many commodity items which do not have to be allowed for now would still be allowed in the future. This economic agreement is doubted by the majority, for it may cause a redistribution of wealth, causing Taiwan to form a huge gap between rich and poor like Hong Kong. It is one of the questions proposed by Ying-Wen Tsai. Tsai also 
pointed out that many Taiwanese have concerns in whether or not ECFA would eventually cause the yielding of sovereignty, and whether China would demand the signing of a cross-strait peace agreement under the principal of "One-China".

Chen (2009) pointed out that Taiwan's opposition parties and the legislature have claimed that before signing the ECFA, the Legislative Yuan must go through the examination process, the so-called "First-trail sign." Before negotiations of ECFA, Taiwan's Executive Yuan must communicate with the Legislative Yuan and the ruling parties to have full understanding of each party's position on ECFA, made a "majority consensus" in Taiwan. Y. $\mathrm{Wu}(2009)$ discussed the policy meaning and the effects on labor rights of signing ECFA from regional economic integration and the relationship between labor rights. Signing ECFA for Taiwan is not just an economic strategy, but also a social and political policy. It must establish an institutional mechanism to deal with labor rights or remedies. Yan (2010) claimed that cross-strait relationships between the two countries have been a key element that develops the constructions of Taiwan. In March, 2008, after being elected as the president of Taiwan, Ying-Jeou Ma actively engaged in cross-strait relations. This change led the DPP, which flaunted Taiwan's sovereign independence, seem alone on the issue. The conflict between Taiwan and China has slowed down on the surface; however, Taiwan is more and more involved into China's system in essence. And other frictions and conflicts are hard to avoid.

On Sep. 3, 2010, Taiwan Referendum Commission of the Executive Yuan turned down the ECFA Referendum proposal of Taiwan Solidarity Union. Hwang (2011) gave a direct proposal for explaining the debate of the Referendum Commission. Under the premise of the loophole in the law, it is possible to arrange for the result as "the majority disagreement".

Yang and Chen (2011) said that due to China's economic development, it has brought good to neighboring countries and signed the Free Trade Agreement. The agreement that concerns the rest of the world the most is between China and the ASEAN-signed FTA. It seems to be a simple economic contract from the literal text of the agreement; however, the attempt of China's government has made others fearful and doubtful.

However, the regional economic integration shows the principle of multiple possibilities. According to a survey of people in Taiwan done by the MAC, $69 \%$ of the people think that institutionalized cross-strait agreements are a benefit to both sides' peace and stability. $79.3 \%$ of people agree that the Taiwan government should continue to talk and deal with Taiwan and China's communication problem.

On agriculture development, Yang (2009) thinks ECFA actually provides agriculture in Taiwan a rare chance of sophistication, refinement and internationalization. The main points are the introduction of new technologies, manipulation of new operation modes, reclamation of new markets, how to integrate resources, build approaches and being creative. These points all open a brand- new value and taste of agriculture.

Hsieh and $\mathrm{Wu}(2010)$ indicate ECFA is also not pure economic cooperation or interaction with China. ECFA only makes Taiwan blend into the world and become a stepping-stone in the economic arena. Although signing ECFA is full of uncertainty for Taiwan, this kind of incoherent development may have much more potential future. Chao, Pan and Chiou (2011) believe that since Taiwan and China signed ECFA, the business relationship between Taiwan and China has become closer and closer. By the time China has adjusted its industrial structure, Taiwan will also have begun to cooperate with this adjustment actively, and incorporate itself into a bigger economy. Taiwan should use "the twelfth five year" project of ECFA from 2011 to 2015 to look for a suitable development mode for Taiwanese businesspeople.

From the perspective of Taiwan's service industry, Chou (2011) thought that because of China's industrial structure upgrades and urgent demands for expanding its domestic market, that the formal implementation of ECFA undoubtedly provided a good opportunity for Taiwanese businessmen to join the development of China's service industry. This two-way investment in service industry and the introduction of human capital will contribute to the close cooperation between two countries' modern service industries.

Lee (2011) analyzed and compared the positive and negative impacts which were brought to Taiwan after signing ECFA. Lee also proposed fourteen indicators that can estimate and measure benefits of ECFA and provided them as a reference for the two countries' policies. Liu (2011) thought that the fact could not be ignored that China's market made a contribution to Taiwan's economy. Furthermore, after signing ECFA, the benefits to Taiwan's economy will become greater. It will further enhance Taiwan's competitiveness and be helpful in maintaining long-term development in economic and political relations between the two countries. In addition to the effect on trade, ECFA also can promote Taiwan's integration in the East Asian economic zone and effectively lift the problem of the marginalization of Taiwan. Zhang (2011) thought that signing ECFA will offer a new impetus for further development of economic and trade relations between the two countries. However on the 
early harvest list of specific implementation and operational agreements, the two countries need long-term communication and conversation. When implementing ECFA, the two countries should put political disputes aside, and focus on the long-term profits, taking both countries interests into account, and achieve a win-win situation.

\section{Conclusion}

We can't deny that the China market has been the area in which the growth number of foreign export trade with Taiwan is the highest. Regardless of whether one agrees or disagrees with the signing of ECFA, the economies of both countries are booming. Further, the economies of other countries in the area are also becoming more stable and each industrial or commercial company is complementary and deeply influences peace and development in the area. After the financial tsunami in 2008 and the impact of PIGS debt crisis in 2011, occident countries are no longer the long-term economic support of Taiwan. We can forecast hereafter, development of Taiwan's industry would be controlled by a global economy and the need to compete keenly with the countries of ASEAN Free Trade Area. Perhaps we will never know the substantial benefit or damage of signing ECFA. Yet undoubtedly, isolationism or protectionism is not a suitable strategy for either or the countries. We should be farsighted about long-term benefit and stable development. However, signing ECFA with China seems to be "a way out of unfeasible ways".

After signing ECFA with China, how to increase the potential between industrials and assist former industrials will be the major issues between both countries. The Taiwan government should show wisdom and boldness so that ECFA can be a critical point of sustainable development of Taiwan industry.

\section{References}

Bureau of Foreign Trade. (2011). Taiwan and mainland China economic cooperation framework agreement. Retrieved from http://cweb.trade.gov.tw/mp.asp?mp=1

Chao, Y. S., Pan, C. H., \& Chiou, S. J. (2011). Study on the impact toward cross-strait economy-and-trade and Taiwan firms' development from China's 12th five-year plan and ECFA. East-Asia Review, 472, 23-54.

Chen, I. H. (2009). The role of ROC's legislative Yuan and political parties in the cross-strait negotiations on economic cooperation framework agreement from the perspective of American experience. Taiwan Democracy Quarterly, 6(1), 177-184.

Chou, C. C. (2011). On the foreground, problems and policy in the modern service industries of cross-strait cooperation during the ECFA period. Journal of Chinese Trend and Forward, 7(2), 43-54.

Hsieh, C. Y., \& Wu, Y. H. (2010). Influence of ECFA to future of Taiwan. Journal of Chinese Economic Research, 8(2), 64-72.

Hwang, S. P. (2011). The anti-democratic referendum law? A critical analysis of the ECFA referendum case from constitutional and methodological perspective. A Journal for Philosophical Study of Public Affairs, 37, 75126.

Karl, W. D. (1978). The analysis of international relations (2nd ed.). New Jersey: Prentice-Hall, Inc.

Lee, L. C. (2011). The analysis on the influence of cross-strait economic development after signing the ECFA. Journal of Chinese Economic Research, 9(1), 51-61.

Liu, W. K. (2011). The effects of economic cooperation framework agreement (ECFA) on Taiwan's politics and economy, and the future prospects. East-Asia Review, 472, 9-20.

Mario, B., \& Ernst, B. H. (1969). The operationalization of some variables related to regional integration: A research note. International Organization, 23(1), 150-160. http://dx.doi.org/10.1017/S0020818300025595

Scalapino, R. A. (1995). Foreword. In J. Khanna (Ed.), Southern China, Hong Kong, and Taiwan: Evolution of a subregional economy. Washington, DC: Center for Strategic and International Studies.

Shaun, B. (2000). Decentralization, globalization and China's partial re-engagement with the global economy. New Political Economy, 5(2), 225.

Soong, J. J. (2009). The new thinking and strategy for cross-strait peaceful development: From economic and trade integration toward political harmony. Review of Global Politics, 28, 63-93.

Taiwan Ratings Corporation. (2009). Taiwan's top 100 corporate credit trends and outlook. Retrieved from http://www.taiwanratings.com/tw

Wu, C. C. (2009). Special cross-strait economy interdependence and meaning. East-Asia Review, 465, 95-105. 
Wu, Y. J. (2009). Regional economic integration and workers' rights: An implication for ECFA. Taiwan Labor Review, 1(2), 179-205.

Yan, J. F. (2010). The difficulties and challenges of Ma Ying-Jeou's China-centric strategy. Taiwan International Studies Quarterly, 6(2), 63-90.

Yang, C. M. (2009). Economic cooperation framework agreement (ECFA) and agricultural production: From the viewpoint of agricultural science and technology. Crop, Environment \& Bioinformatics, 6, 247-252.

Yang, K. F., \& Chen, J. X. (2011). An overview of ECFA from the rising of China and ASEAN FTA. East-Asia Review, 472, 69-95.

Zhang, C. (2011). ECFA: The new height of cross-strait economic and trade cooperation. Theory Monthly, 2011(3), 133-136.

\section{Copyrights}

Copyright for this article is retained by the author(s), with first publication rights granted to the journal.

This is an open-access article distributed under the terms and conditions of the Creative Commons Attribution license (http://creativecommons.org/licenses/by/3.0/). 